\title{
Malaise of British science
}

SIR-The polemic of Theocharis and Psimopoulos against recent philosophers of science (Nature 329, 595-598; 1987) deserves to widely read, and as widely quoted. Yet I urge that the way forward will not be to denounce the contributions of these philosophers, but to see them in perspective.

I teach a (very short) course in philosophy of science to honours science students in their final year. I feature Popper, Kuhn and Lakatos, and I use Chalmers' book: of the devils denounced by Theocharis and Psimopoulos, only Feyerabend seems to me too deliberately destructive to be worth attention. The others are seriously striving to identify aspects of the scientific process. If their accounts are unbalanced, it is up to us to balance, not dismiss them.

Popper began it all by his concern to distinguish good science from bad. He identified Einstein as good and Adler as bad by characterizing Einstein's predictions as falsifiable but not as false. Falsifiable predictions were simply firm, clear predictions; predictions which explicitly required that the contrary did not occur. If it had occurred, they would have been falsified and (Popper judged) Einstein, unlike Adler, would have accepted that he was wrong and not tried to talk his way out of the fact. "Falsifiable" did not mean "seeking to be falsified", it just meant "strong enough to stand up and be counted on one side, not the other". I share the view that the next stage of Popper's thought sees him following up certain ideas to unbalanced and therefore somewhat antirational conclusions, but this first, key perception is firmly on the side of objectivity and truth. This is the one bit of Popper that I teach.

The theory-ladenness of observation must be recognized - but I teach it from Hanson, rather than Popper. It is a feature of the human mind to which we must face up: you will "see" (notice as significant) not "what you are looking for" (that, of course, is prejudice) but "the kind of thing you are looking for" (its presence or its absence). Not to make our young people aware of this would be to send them out into the laboratories as more naive scientists, not as more objective ones. But no hard-nosed industrialist can object to this: if he enquires into our procedures, he should be keen to known not only what questions we propose to ask but what kinds of observation we shall accept as answering them.

Kuhn is not wrong either. Every now and then great theories fall, and are replaced. More minor ones fall daily. Moreover, ideas sometimes return, after periods in the wilderness. These processes are not irrational, as Kuhn, growing tired, concluded, but they occur - and it is up to us to work out their rationality. Lakatos, with his "protective belts of auxiliary hypotheses" and his "positive versus negative heuristic" makes, it seems to me, a constructive first attempt. But there is much more work to do, if a positive account of theory-change, which satisfies both the observations of Kuhn and the aspirations of Theocharis and Psimopoulos, is to be constructed.

Meanwhile, however, it will be only our own bad salesmanship that will let the lack of this complete account lose us money. Every industrialist I know accepts that science, being merely human, does not provide certain knowledge of the fundamental structure of the world (although of course he assumes, quite rightly, that it is continually striving towards this). $\mathrm{He}$ is, however, a tacit disciple of a much earlier philosopher of science - Bacon. What the industrialist wants is "not knowledge of nature, but power over nature". That power, science provides; when we do good science we shall reach right conclusions about matters of fact even though it is always possible (as the recent philosophers have been pointing out) that we are being right for the wrong reasons).

Institute of Physiology,

The University, Glasgow G12 8QQ, UK

SiR--Philosophers have always been accused of corrupting youth and subverting the state. The fashion began in Athens when Socrates was tried and executed on those charges. The anxious, the ill-informed and the unimaginative among his contemporaries were unable to tolerate a man whose wisdom lay in knowing how little he knew and whose method was to pose uncomfortable questions about the status of 'what everyone knew'. The Commentary by Theocharis and Psimopoulos (Nature 329, 595-598; 1987), makes it clear that times have not changed.

The real tragedy of their analysis lies in how little good it will do for the cause of science. They argue that science is being starved of necessary funds and they blame philosophers for that state of affairs. Philosophers, they say, have not been enthusiastic enough about the ability of science to yield truth. Is there anything in these charges? Certainly, philosophers have often sought to analyse the nature of science rather than to celebrate some abstraction called 'the scientific method'. That is to say, philosophers have given free rein to their intellectual curiosity and sought disinterested knowledge. In so doing, they have merely behaved like scientists.
But Theocharis and Psimopoulos produce no evidence that anything philosophers have said - whether positive or negative - has ever had the slightest effect on government finance. The nearest they get to an argument is to commit the fallacy of concluding 'after that; therefore because of that'.

There is, of course, every reason for serious concern at the state of government support for scientific research. Philosophers, sociologists and historians of science share scientists' concern, and it is natural that they should do so. Anxieties about the crisis in science should be addressed directly to those who hold the purse-strings. They should not be deflected into attacks on academic colleagues whose disciplines are under similar pressure. It is both a sign and a cause of weakness not to recognize one's true enemy.

David BLOOR

STEVEN SHAPIN

Science Studies Unit,

University of Edinburgh,

34 Buccleuch Place, Edinburgh EH8 9JT, UK

SIR-Theocharis and Psimopoulos (Nature 329, 595; 1987) have described what they consider to be the fundamental factor in the decline of support for science, namely the failure to establish its epistemological basis. This rather theoretical assault comes, however, mainly from academics who have never practised science and cannot see its cultural value. It is the latter aspect, involving the sociology of science, to which we should pay attention.

A striking feature of the postwar scene is the steady decline in the calibre of scientists called upon to advise governments. The present adviser to the US president is a former deputy director of the National Aeronautics and Space Administration, a post to which he graduated from 'weapons expert', and whose role in the shuttle disaster raised numerous questions (at the time of the launch he was advising the president on public relations). Even more heavily underlining the divorce between knowledge and power is the 'Star Wars' proposal to militarize space, shown to be nonsense and unanimously opposed by practising scientists. When one puts this beside the the very menacing problems of global ecology, one might agree with Spengler in pronouncing the decadence of the West.

Ultimately we have to appeal to the good sense of the man in the street. There are good reasons for doing science: not only our appreciation of nature but our survival on this planet depends on it. If social and political institutions do not recognize this we must change them.

M. C. Goodali

3 Robson Terrace, Shincliffe Village,

Durham, DH1 2NL, UK 